\title{
jip \\ Analysing the Intersection of Marxist and Postcolonial Paradigms in Selected Pakistani English Fiction
}

\author{
Asim Karim \\ Department of English | University of Central Punjab, Lahore \\ asim.karim09@gmail.com
}

\section{ABSTRACT}

This paper analyses the intersection of Marxism and postcolonial paradigms in selected Pakistani English fiction. Invoking debates on classical Marxism and postMarxism, especially Louis Althusser and Fredrick Jameson, this paper discusses areas of class, class consciousness, and ideological class structures in the selected fiction of Daniyal Mueenuddin's In Other Rooms OtherWonders, Raza Rabbani's Invisible People, H. M. Naqvi's Home Boy, and Nadeem Aslam's Maps for Lost Lovers. The study also invokes Jameson's thoughts on imperialism to analyse the first world/third world dichotomy, and the growth of third world voices within imperial metropolises. This selection of fiction is warranted for the reason that Pakistani fiction does not generally approximate major facets of class and the changing dynamics of capitalism in today's globalised world. In doing so, this paper explicates social realism in Pakistani fiction from a broad range of Marxist and post-Marxist theoretical perspectives, thereby highlighting class variations in Pakistani fiction. It also signifies how Pakistani fiction in English is coping with the changing dynamics of global capitalism while foregrounding how Pakistan, as a postcolonial state, is grappling with the feudalcapitalist system, class stratification, wide rural-urban divide and uneven economic development.

Keywords: Marxism; post-Marxism; class consciousness; Pakistani anglophone Fiction 
Marxist literary criticism generally positions a literary text as a reflection of an objective social reality and one of the ideological forms in the ideological superstructure $^{1}$. However, this objective social reality is not tied to the conventional relations between the bourgeois and the working class. Contrarily, it has undergone a phenomenal development in meaning, especially under the impact of post-Marxist/post-structural ideas and now it includes racial, feminist, and sexual issues in the global context. Furthermore, thoughts on imperialism as an international mode of production and consumption (Cultural Turn 67) has also expanded Marxist ideology to extraterritorial mechanisms of the capitalist economy. Postcolonialism has also displaced the Marxist problematic from Eurocentrism to Third Worldism, (Larsen 50), 'from 'class' to 'nation' and 'capitalist' social relations to 'core/periphery' or 'First World/ThirdWorld' social relations, with obvious inevitable consequences for the reconceptualization of the agency and geopolitical vectors of imperialism" ( Larsen 50). In this context, this paper is among the few comprehensive studies of selected Pakistani English fiction in relation to the intersection of the Marxist and postcolonial paradigms.

To start with, the relation between Marxism and postcolonial theory is entangled in disputes and reconciliations ranging from "relative isolation" (Hall 258) to active engagement through Gayatri Spivak's self-proclaimed feministMarxist- deconstructionist portfolio. It is also apparent in Frantz Fanon's problematic of decolonisation which sees the postcolonial/post-liberation period in countries like Pakistan manifesting the rise of a new ruling bourgeois class, reinforcing class structures to their advantage. Therefore, a postcolonial analysis of a Pakistani work cannot be dissociated from the debates on economics and class relations. Bart Moore-Gilbert explicates in detail how both Marxism and postcolonialism have moved from a troubled relation to assuming reconciliation. The discussion in this regard, however, is not an account of the complicity between class relations and class struggle as is expostulated in the classic Marxist ideology. It needs to bring in the key post-Marxist position on class and how it could be interlinked with the rise of new colonialism in Pakistan to explain how Marxist ideology of class struggle and global capitalism interact in contemporary Pakistani English fiction. The selection of the fiction analysed here is justified on the grounds that no single Pakistani English text approximates the major ${ }^{1}$ Alan Swingewood construed three main categories of Marxist literary criticism from the writings of Marx and Engels: "I. literature as ideology forming an essential component of society's 'superstructure' and reflecting significant aspects of economic, social and political structure; II. The discussions of literary realism in which a foundation is suggested for critical judgment; III. Those writings which grasp literature as an historical and creative activity requiring genetic and dialectical analysis" (131). Marxist approaches to the study of literature Alan Swingewood. The Sociological Review. 1977. 05 vol. 25. 
components of classic Marxism and the changing pattern of capitalism in the modern globalised world. My present study articulates these troubled relations and possibilities of reconciliation between the two streams of ideas. It debates how Marxist / post-Marxist positions on class can be interlinked with neocolonialism to debate ideology and global capitalism in contemporary Pakistani anglophone fiction. It invokes debates on Marxist and post-Marxist theory to analyse the above outlined issues in the selected works of H.M. Naqvi's Home Boy, Daniyal Mueenuddin's In Other Rooms Other Wonders, Raza Rabbani's Invisible People and Nadeem Aslam's Maps for Lost Lovers. What makes my contribution timely is that it explicates the analysis of social realism in Pakistani anglophone fiction from a broad range of Marxist and post-Marxist theoretical perspectives like Fredric Jameson's views on third worldism. It also debates how postcolonial Pakistan is grappling with a feudal-capitalist system, class stratification, a wide rural-urban divide and uneven economic development. It further discusses how Pakistani anglophone fiction moves forward to address post-Marxist approaches regarding capitalist exploitation of the oppressed labour class in Pakistan. What needs to be seen is how Pakistani fiction moves ahead while addressing Jameson's thoughts on global capitalism, internal third world voices and Spivak's critique of neocolonialism wherein knowledge serves as a means of capitalist production. The available studies are predominantly tilted towards postcolonial issues, such as by Nahem Yousaf, Cara Cilano, Rehana Ahmed, Madelline Clements and Aroosa Kanwal. Thus, the present study brings interweaves varied Marxist/post-Marxist perspectives to debate a range of class issues in the selected Pakistani fiction.

\section{Class, and Economic Development}

Marxism is the rise of a new economy where the dispute is between control over means and resources of production in an industrial context. It moves from the conventional feudal class system to modern capitalism, where different class relations are defined and determined by specific economic forms (Katz 365). The subcontinent, however, does not fully accord with the developmental phases of modern capitalism. Contrarily, it indicates a concordance between the capitalist and the feudal in a way which questions the different phases of the growth of Western capitalist economy. It amalgamates feudal and capitalist systems to remain in full control of property relationships, especially during of the Imperial British Raj. Gail Omvedt argues that British imperialism produced a colonial working class that co-existed with

feudal ties of dependence in agriculture. The most adequate way to conceptualise this situation is in terms of the existence within the Indian 
social formation of feudal (Agrarian and proto-capitalist (mines, plantations, factories) sectors or modes of production which were articulated in such a way that the main costs of reproduction of the labour-power that is sold in the capitalist sector is borne in the noncapitalist agrarian sector. (186; emphasis in original).

In colonial India, the peasantry operated as a class of subordinate /bonded labour, tied to farming as families on low wages. They neither owned the land, nor had any control on any part of the agricultural production except for providing labor. In his detailed argument, Omvedt establishes a connection between the deleterious colonial capitalist regime and its practices in the Indian subcontinent: Millions of agricultural labourers rendered surplus by the decaying agrarian economy of India formed the source of supply of labour for this developing industry.

This statement assumes a certain factual model of the way imperialism worked on the Indian economy as a whole, agriculture as well as industry. This model is approximately as follows: (1) Colonial rule imposed bourgeois private property in land and subordinated Indian agriculture to the world market, i.e. established commodity production, with the general result of impoverishing and proletarianising a large portion of the peasantry. (2) Nevertheless the vast majority of such proletarianised peasants, though they were agricultural labourers freed from 'feudal' ties or rights to the land, could not find work because of the limited development of industry and the lack of capital accumulation, i.e. real capitalist development in agriculture; therefore they remained 'bound' to agriculture itself and, continued to be dependent, often through debt, on landlords and moneylenders. The model thus assumes that though imperialism acts to transform agriculture-i.e. it 'disintegrates' and 'dissolves' the traditional village structure - it is precisely because of its thwarting of industrialisation that backwardness in agriculture and dependence is maintained (185-186).

In like manner, the social structure in post-independence Pakistan is also essentially a combination of the feudal-capitalist class formation, enunciating extreme control of both land and industry for the perpetuation of specific class interests. Thus, fundamentally, the bourgeoisie in Pakistan deviates from the growth of the capitalist economy for the reason that it combines feudalism and capitalism as a single tool in national development, engendering absolute control/dominance of class relationships. Thus, Pakistan represents a compact state system, combining elite capitalists, feudalists, and bureaucrats dominating the social/class system in a rigid fashion, even obliterating the possibility of the proletarian revolution. This can very well be seen in Mueenuddin and Mian Raza Rabbani's short story collections.

Mueenuddin's short story collection is an archetypal representation of the Pakistani class structure, implicating historical materialism, private capitalists, 
and feudal structures in a complicated framework of bourgeoisie control and manipulation of the means of production. The coalition and concordance among disparate elite classes, presented here through the elite figure of K. K. Harouni, eludes any classic interpretation of capitalism or bourgeois. He serves as an internal link for solidifying bonds between different elite groups / classes in Pakistan and represents the complex blend of the feudal-private capitalist, abundantly rich and privileged class that controls a vast array of working class, that is the peasants and personal servants, etc. In Pakistan, the peasantry is normally composed of small family units which naturally preempts their developing any class-based network to engage in any consolidated effort to resist feudal lords. Peasants live in abject poverty, bereft of basic amenities of the household like electricity. They might feel compelled to engage in 'off-farm' activities to manage most of the household expenditures. The protagonist, Nawabdin Electrician in the first story is an exact enunciation of this situation. Existing in perpetual servitude, Nawab is happy to serve the interests of his feudal master and is least inclined to seek freedom from bondage or to participate in any struggle to dismantle the class structure. Contrarily, he shows a willingness to continue with his low paid and economically deprived condition in return for minimum rewards such as receiving a motorbike from the master. In return, he continues to be loyal to K. K. Harouni and serves him even beyond his skill and capacity. He unscrupulously pilfers electricity from the grid to run as many as seventeen tube wells on K. K. Harouni's farms that are spread across acres, and travels long distances on his old bicycle to repair faulty tube wells in order to ensure their unhindered performance on pilfered electricity. A similar sense of servitude and serfdom is indicated by Jaglani, K. K. Harouni's Munshi, his manager, who is even responsible for the sale and purchase of his lands and agricultural produce from the farms to the market. Obviously, both indicate a class system where not only do the privileged enjoy complete authority and domination over resources, but also where the servants are kept in permanent subordination through lack of equitable economic development and skill-based education. Hence, their impoverishment serves the interests of the capitalist-feudal power structure.

However, the working class, as represented by Jaglani, is absorbed in pursuing selfish interests to amass wealth and a relative position of power at the behest of their Master. Jaglani, in particular, indicates a crucially cunning tendency to plot against his master, and erode K. K. Harouni's absolute control over the means and resources of production. Relying on fraud as an appropriate tool of erosion, Jaglani traps Harouni, when he gets bankrupt due to a lavish life style 
and spending, to sell his lands at much cheaper rates. First, he convinces Harouni of the fall in land prices in such a way that he is compelled to sell his lands in haste, and later starts transferring his costly land to his relatives in the garb of fraudulent sale deeds. Thus, acting clandestinely, Jaglani manages to appropriate a huge chunk of Harouni's land and becomes a local feudal with the ability to contest elections in order to gain access to electoral politics. Both instances draw attention to the bulk of the unprivileged classes living in ignorance as well as lacking in skilled-based knowledge which hinders their social mobility. On the other hand, people like Jaglani cunningly exploit their ignorance and the system for their personal gains.

\section{Class Consciousness}

Class consciousness is essentially rebellious, reflecting the working class' political consciousness and will to revolt against the bourgeoisie. It results from past conflicts, especially with the bourgeois, inherited by each generation of the working class. Class consciousness is contingent upon class position (Wright 12). But the matter is far from a simplistic enunciation of power dynamics in a society where the population is divided between rural and urban settlements. In the rural environment of countries like Pakistan, the class system is substantially different from the urban areas. Poverty, low level of education, high percentage of illiteracy, and lack of resources keep peasants trapped in permanent servitude without the possibility of emancipation or manifesting what Anthony Giddens calls "class conflict consciousness" (112-113). Hence, it represents a static position of class consciousness which severely undermines what Antonio Gramsci call the processual view of class consciousness. The only way which could assist in developing this processual view is developing organisations through unions, parties or movements which serve as the determination of class consciousness in the working classes (qtd. in Hobsbawm 14).

Nawabdin Electrician powerfully reflects a lack of class consciousness in the agricultural working class on lands and farms in particular. The stress on the working class in this consciousness naturally places the peasantry out of the Marxist focus. Additionally, their lack of class consciousness reveals the absence of an active social identity that has paralysed the possibility of any movement against the bourgeoisie and preempts the agricultural working class from playing any transformative role in improving their economic status. This absence of class consciousness contradicts the Marxist prediction of the increase in class conflict, ending at the proletariat revolution. Many Marxists today argue that while the 
'objective' conditions for a proletarian revolution exist or are relatively advanced, the workers' 'subjective' consciousness of their historic role lags behind.

Foregrounding the uneven economic development in the aftermath of colonisation, E. San Juan Jr. paces his argument with the dialectical assessment of imperialism as propounded by Gramsci and others in the "Marxist-Leninist traditions", and argues:

In many societies shaped by colonial conquest and imperial domination, uneven and combined development is discernible in the co-presence of a modern sector (usually foreign dominated or managed by the state) and a traditional sector characterized by precapitalist modes of production and ruled by merchant capitalist and feudal/tributary ruling classes. In these peripheral formations, we find a lack of cumulative growth, backward agriculture limited by the lack of an internal market, with the accumulated money capital diverted from whatever industrial enterprises there are into speculative activities in real estate, usury, and hoarding. (232)

Within urban areas too, a dehumanising and imbalanced economic gap between the growth of the elite and the poor is discernible. In countries like Pakistan, the state is predominantly guilty of dividing the population into the haves and have-nots as is witnessed in a capitalist scenario. Impoverished slums, lack of adequate social, educational and health amenities for the majority of people and uneven infrastructural development across the rural-urban canvas bear testament to this scenario. Fatima Bhutto's The Runaways realistically sketches the life and impoverished conditions of the people living in such mega cities as Karachi. Even state institutions like the police are more inclined to oppress than support the marginalised. Similarly, in "The Flower of Dust", Rabbani exposes the state's bourgeoisie-like control of public resources for the maintenance of elite culture and depriving the majority of the population of its fundamental human needs like adequate health care. For instance, the majestic stone-built hospital for the common people (constructed during the British rule) has only served the "higher grades of bureaucracy, as well as their families and friends, while professing to be a government hospital for all" (Rabbani 30). Right in front of this magnificent building, we find a worn-out man who might be "a worker in cotton factory, a cog in the wheels of industry, a turner of profit for the textile magnates" and is in deep trouble, writhing with his "failing lungs today on the cemented bench in front of the government hospital” (Rabbani 30). Denied even entrance into the hospital, his agonising thoughts and "dialogue with his creator" (Rabbani 31) inadvertently reveal his existential incongruity within the given condition of the socio-economic divide: "am I not the citizen of the state, do the constitutional rights of 'from each according to his ability, to each according to his work' not apply to me? Are my 
children destined to be chattels?" (Rabbani 31). In Mueenuddin, the imbalance between the urban and the rural has also been thoroughly maintained. While the Harounis enjoy urban life in rich mansions and luxuries abroad as is witnessed in his short story, "Our Lady of Paris", the peasantry and the rural population have to live in penury and extremely weak infrastructural facilities like dirty roads and sparse health care facilities. The government clinic, for instance in Nawabdin's story is a dirty place, "smelled of disinfectants and bodily fluids, a heavy sweetish odor... blood on some rumpled [bed] sheets" (Mueenuddin 26).

Mueenuddin's own affiliation in his collection is rather openly placed. He neither sides with the capitalists nor sympathises with the proletariat. He seems to move indiscreetly between the two by implicating them in depravity, debauchery and opportunism. K. K. Harouni is as much a debauch as his Munshi (Manager) Jaglani. Likewise, the elite Lily and very poor Saleema and Husna are connected in sexual transgressions. Adultery in particular is common in the elite as is seen in Lilly's sexual antics with her boyfriend Bumpy, and Saleema's sexual relations with the male servant Rafik. K. K. Harouni himself is a debauch as he sexually manipulates his maids: "As a boy Harouni slept with his maid servants; lost his virginity to one of them at fourteen. Husna evoked those ripe first encounters" (Mueenuddin 122).

Closely attached to the description of class structure is the focus on the minute details of the social life of the labor class. The description is offered to explicate their miserly existence in relation to the bourgeoisie and how commodification and exchange value determines their lived reality as something that cancels out any possibility of a proletarian revolution. This recalls Theodor Adorno's Social Theory which recapitulates historical materialism as a method which brings to light things written from the point of view of the "vanquished", those "who fell by the wayside", "the waste products and the blind spots", (Adorno 151) and "the material specificity of the minute particulars uncovered by the historical and philosophical inquiry" (Jarvis 84). Keya Ganguly in her discussion writes that Adorno's pursuit of historical materialism, "emphasizes the force of ruling ideology which tendentiously rides over not just subordinated histories and points of view but denies the validity of their existence at all" (244). Furthermore, she postulates:

That such material has outwitted history, gives it an agency that is its own, not simply one that relegates it to the status of a supplement in the dominant historical narrative. Also, insofar as such material is "opaque" or "unassimilated," it is more than an effect or a trace of the subaltern's inability to speak in any deconstructive sense. It is material that stands in opposition 
to ruling modes of understanding and, by that token, signifies meanings that actively belong to a distinct - not merely semanticized or translated reality. (Ganguly 245; emphasis in original)

In Mueenuddin's collection, the "vanquished" are employed on farms or personal estates but paid very low wages in exchange for their value. The description of their minute particulars relates to their personal and individualistic modes of existence, also implicating the commodification of their bodies (in case of women), commodity fetishism and intrinsic value of labor. But the amount of value these "vanquished" inculcate in the system and the wages they are paid in return are not essentially transformative since they do not anticipate the possibility of their developing a class consciousness in order to revolt or achieve a respectable existence. It is simply existential. In "Nawabdin Electrician" as mentioned above, Nawabdin's life is in a state of personal bondage to Harouni, and his skills in managing the electric gadgets are knowingly utilised to pilfer electricity for selfserving interests. But despite all his labour and (mis)deeds, he is not paid enough to run his growing household, which comprises of his wife and twelve daughters, comfortably. Therefore, not only does he pilfer electricity for domestic use, but also remains engaged in 'off-farm' activities like fixing watches and broken radios for resale etc. Mueenuddin's story "Provide Provide" is saturated with minute descriptions of the harvesting peasantry, both women and men, "moving across the yellow fields, and setting up the cut bundles into shocks. Their babies swung in clothes strung in the shade between trees" (Mueenuddin 67). Closely tied to these peasants are domestic laborers, especially in the urban centers where mostly women and children are preferred for manual labour because they are obviously more vulnerable to exploitation because of their willingness to work for low wages. Saleema and Husna in Mueenuddin stories, Ahmed who is a street laborour, the ten year old Jaan and Rani in Rabbani's stories belong to the class of domestic laborour.

\section{Althusserian Perspective}

Althusser is crucially important here as he anticipates the Foucauldian knowledge/ power theory (Foucault's belief that institutional practices, rather than theoretical ideals, reproduce the subject) and Butler's "performative acts" (xxix). Althusser exposed how capitalism maintains and disseminates its system through ideology. His key idea pertains to the "Ideological state apparatuses" or ISAs, which, unlike the Repressive State Apparatus, works clandestinely, and instead of using force or correction manages to elicit subordination through implicit consent for the perpetuation the established practices (Leitch and Cain 1477). Family, church, 
school, media, arts and even sports are included in the list of ISAs. In Invisible People, the idea of the family operating as an ISA unit is explicitly narrated in the short stories titled "Broken Dreams of Boy" and "Brewing". Sarcastically sketching the "real Pakistan" (Rabbani 63) in "Broken Dreams of Boy", Rabbani draws attention to how domestic labor and street labour are produced because the labouring class strives to maintain a scanty inflow of wages for bare existence. Habib's father, a factory worker, "died to an electric short circuit" (Rabbani 58), leaving behind a humbled wife to work as a domestic laborer in "five different households" to support three children. Still, her monthly income of four thousand rupees (FortyFive dollars) earned in a six-day week from 7 a.m. to 6 p.m. was not sufficient even for a meagre existence. As a minor, Habib is, therefore, compelled to seek self-employment as a street laborer to clean cars on bus stops. He also started earning a little amount by car polishing. In "Brewing", Jaan is compelled by his sick father to leave school and work for supporting the family.

Quite differently, from these ideological structuring of the impoverished class, but very relevant to the ideological class structuring, is the use of religion as an ISA. Aslam's Maps for Lost Lovers distinctly presents how religion can be used as an ideological factor within the family to produce a bigoted and extremely intemperate mindset in women. According to Kanwal, despite living in London all characters in this novel, "the people of Dasht-e-Tanhai", are trapped "within their cultural cocoon" and are completely isolated from each other (159). Kaukab is the most alienated among them. Despite living in England for years, Kaukab does not know "where and how ... you get a taxi in a strange city'” (qtd in Kanwal 159). In my view, her deeply religious conditioning is thoroughly connected with her initial culturalisation back home that promotes an irrational and fanatical mindset, which manifests itself in the rigid assertion of one's own regimes of truth. Even before moving to London, she shows visible traces of religiosity that breeds intolerance and parochialism. During her stay in London, she exhibits the most irrational and fanatical attitude in her relation with the non-Muslim whites. The whiteness of the English people is taken as polluted. Therefore, she considers it repulsive to live in London with the whites. It also reflects her deep-seated antipathy and intolerance towards the people adhering to religions other than her own. Her thoughts remain fixed on exteriorities such as the white color of the body, sinfulness and the need to take a bath to purify the body of pollution. Her fanaticism is informed by her own assumed ideas of purity instead of impure bodies of people from other faiths. This bias is apparent in her response to the news that Jugnu would bring his white girlfriend for dinner: "She wept as she 
prepared food in honour of Jugnu's white woman - a feast celebrating the fact that they were sinners" (Aslam 48). In one of the most provocative thoughts, she aligns non-Muslims with abject pollution and sinfulness: "who was this white woman? How clean was she? for instance: did she know that a person must bath after sexual intercourse, or remain polluted, contaminating everything one come into contact with? . . . [she] had touched the white woman and would have to change her clothes to be able to say her next prayers" (Aslam 54).

\section{Fredrick Jameson and "Internal Third World Voices"}

First World/Third World classification is even structured within the imperial metropolis, where the imperial subject tends to perceive colonial migrants as the other in a "condition of subordination or dependency" (Jameson, "Modernism and Imperialism" 48). A specific shift in the meaning appropriated to the third world, writes Jameson, has taken place which is not merely related to the "decolonization and political independence" of third world countries, but also because "these enormously varied cultures all now speak in their own distinctive voices" (Jameson, "Modernism and Imperialism" 48) , impacting "not merely other Third World cultures as such, but First World literature and culture as well" (Jameson, "Modernism and Imperialism" 49). He also talks about "the emergence of an "internal Third World and of internal Third World voices" in Europe and America (Jameson, "Modernism and Imperialism" 49). An example of this emergence is black women's literature or Chicano literature. The impact of these voices is meaningful. It emphasises the sense of possibly being the problematic Other within the imperial metropolis, "When the other speaks, he or she becomes another subject, which must be consciously registered as a problem by the imperial or metropolitan subject", which in turn might drive "largely Western theories of imperialism in a new direction, toward that other, and toward the structures of underdevelopment and dependency for which we are responsible" (Jameson, "Modernism and Imperialism" 49).

These thoughts definitely carry an implication for the Muslim diaspora in the West. This is because after 9/11, Muslimness has assumed a stereotypical class formation accruing a sense of anxiety in the process as it is seen as a problem in the West ${ }^{2}$. Eundamentally, being a Muslim now represents a condition of ${ }^{2}$ Haideh Moghissi in the Introduction to her monograph, draws attention to the similar solidification of third worlds in the European metropolis: "What seems to be happening in Western metropolises today is the construction of geographically and socially distinct localities of 'Muslim' populations and the formation of a sort of collective identity and or group affiliation among this nominally Muslim population". (xiv). Furthermore, Islamic identity is at the bottom of this tendency: “... Neither does it overlook the fact that some forms of Muslim cultural expression are extreme, and invite unfriendly and intolerant reactions from the host. Admittedly, all this only provides more fuel for psychological 
dependency on the Western acceptance as is seen in Home Fire, particularly in Karamat Lone's speech to the Muslim community in the UK. Muslims might also be seen as financially unstable, looking for jobs like the disgruntled Pervaiz in Home Fire or choosing to drive cabs for a menial wage as in Naqvi's Home Boy. But more than economic decline, the religious identity underscores the process of a different kind of Othering where religious identification has overwhelmed the generalised notion of third world voices in the imperial metropolis. Furthermore, this Othering enunciates a peculiar signification, that of fundamentalist Islamists for ideological management through ISAs or their exclusion through repressive state apparatuses like the police, immigration and homeland security.

In this context, Naqvi's Home Boy and Shamsie's Home Fire ironically question the notion of 'home' to expose the above mentioned ideological positions. In Home Boy, three Pakistani diasporics in the US are implicated in the ideological production of a specific identity which is suggestive of a radical position of Muslims in the USA, causing alarm, suspicion and anxiety in the host society. Though fully engrossed and assimilated in the secular/modernist culture, Ali Choudhury (AC) proclaims himself a self-respecting Muslim atheist, even as he blasts all religion including Islam. Islam to him, is "not good and peaceful, chum ... It's a violent, bastard religion, as violent as, say, Christianity, Judaism, Hinduism, whatever" (Naqvi 97 ). Chuck (Shehzad Ali) also represents a similar assimilation into Americanness as he declares that one can "spend ten years in Britain and not feel British, but after spending ten months in New York, you were a New Yorker, an original settler" (Naqvi 15). In the First World metropolis, these third world subjects struggle to claim their legitimate position there. On the contrary, the presence of these Muslim migrants in the aftermath of $9 / 11$ is forestalled as trouble and elicits negativity: "You could feel it walking down some streets: people didn't avert their eyes or nod when you walked past but often stared, either tacitly claiming you as their own or dismissing you as the Other" (Naqvi 45). When Shahzad, AC and Jimbo are taken by the FBI agents for supposedly being involved in terrorist activities; "the three friends are interrogated at Manhattan's notorious metropolitan detention center; denied phone calls on the pretext that being not Americans, they "got no fucking rights" (107). The questions asked are: "some warped catechism ... You are a terrorist?

resignation for both the 'Muslim diaspora' and the host society, solidifying a marginal location for the diasporic population and deepening racist policies within the host country. The point, however, is that the dichotomizing classification of diasporic Islamic cultures, which sets people apart from the rest of the population, to a large extent helps determine how they behave and how they respond to the pressures of resettlement in a new society" ( xv) . Moghissi, Haideh, ed. Muslim Diaspora: Gender, Culture and Identity. Vol. 2. Routledge, 2007. 
... You are a Muslim? .... So you read the Koran? ... You keep the Ramadan? ..... Do you eat pork? .....Drink? .....Won't Allah get mad?” (Naqvi 113). The trouble does not end here. After their release from the grilling, Chuck is scolded by the Pakistani community in the US for bringing shame on Muslims the way the Taliban did in blowing up the Twin Towers. He has a sense of being a "marked man" - a petrified "Other"-forced to leave the country. Thus, the economic class stratification here is diversified into first world/third world class conflict with possibilities of generating a specific third world consciousness at the center of American metropolitan politics. In Home Fire, Isma, a British passport holder from Pakistan, undergoes a similar process of Othering at the Heathrow airport.

The paper analyses class and capitalism from a wide range of Marxist and post Marxist perspectives. It has debated how varied representations of class consciousness and new facets of capitalism continue to be highlighted in the contemporary Pakistani English fiction. Thus, the paper has emphasised the significance of Marxist thoughts in interpreting changing dimensions of class conflicts and bourgeois domination in postcolonial Pakistan. At the end it encourages to focus on how Pakistani fiction invokes serious debate on literature as an ideological form, and a permanent source of production for the elitist Imperial bourgeoisie. 


\section{Works Cited}

Adorno, Theodor W. Minima Moralia: Reflections from Damaged Life. Trans.

E. F. N. Jephcott. London: Verso, 1978. Print.

Aslam, Nadeem. Maps for Lost Lovers. London: Faber and Faber Limited, 2004.

Print.

Bhutto, Fatima. The Runaways. London: Penguin, 2018. Print.

Butler, Judith. Gender Trouble: Feminism and the Subversion of Identity. 1999. Print. NY: Taylor and Francis e-Library, 2002. Print.

Ganguly, Keya. “Adorno, authenticity, critique.” Marxism, Modernity, and Postcolonial Studies. Bartolovich and Neil Lazarus. Eds. Cambridge:

Cambridge UP, 2004. 240-256. Print.

Giddens, Anthony. The Class Structure of the Advanced Societies. New York:

Harper and Row, 1973. Print.

Moore-Gilbert, Bart. "Marxism and Postcolonialism Reconsidered."

Hungarian Journal of English and American Studies (HJEAS) 7.2

(2001): 9-27. Print.

Hall, Stuart. "When was 'the post-colonial'? Thinking at the limit." The

Postcolonial Question. Routledge, 2002. 248-266. Print.

Hobsbawm, Eric. "Class consciousness in history." Aspects of History

and Class Consciousness. Ed. I. Meszaros. London: Routledge \& Kegan

Paul, 1971. 5-21. Print.

Jameson, Fredric. The Cultural Turn: SelectedWritings on the Postmodern, 1983-1998. London: Verso, 1998. Print.

---. Postmodernism, or, the Cultural Logic of Late Capitalism. Durham: Duke UP, 1991. Print.

---. “Modernism and Imperialism”. Nationalism, Colonialism, and Literature. Vol. 1. Minnieapolis: U of Minnesota P, 1988. 43-69. Print.

Jarvis, Simon. "Adorno, Marx and Materialism". In Tom Huhn. The

Cambridge Companion to Adorno. Cambridge. 2004. 79-100.

Jones, Andrew. W. "Caring Labor and Class Consciousness: The Class

Dynamics of Gendered Work” Sociological Forum 16.2 (2001): 281-299.

Print.

Juan, E. San. Jr. "Postcolonialism and the problematic of uneven development". Marxism, Modernity, and Postcolonial Studies. Eds. Crystal Bartolovich and Neil Lazarus. Cambridge, 2004. 221-239. Print.

Kanwal, Aroosa. Rethinking Identities in Contemporary Pakistani Fiction: Beyond 9/11. Basingstoke: Palgrave Macmillan. 2015. Print. 
Katz, Claudio J. "Karl Marx on the transition from feudalism to capitalism." Theory and Society 22.3 (1993): 363-389. Print.

Lazarus, Neil. "The fetish of 'the West' in postcolonial theory". Marxism, Modernity, and Postcolonial Studies. Eds. Crystal Bartolovich and Neil Lazarus. Cambridge, 2004. 43 -64. Print.

Leitch, Vincent B., and William E. Cain, eds. The Norton Anthology of Theory and Criticism. London: W.W. Norton \& Company, 2010. Print.

McLellan, David. Marxism after Marx: An Introduction. Third edition. London: Macmillan, 1998. Print.

Mueenuddin, Daniyal. In Other Rooms, OtherWonders. London: Bloomsbury, 2009. Print.

Naqvi. H.M. Home Boy. New York: Harper Collins. 2010. Print.

Omvedt, Gail. "Migration in colonial India: the articulation of feudalism and capitalism by the colonial state." The Journal of Peasant Studies 7.2 (1980): 185-212. Print.

Rabbani, Raza. Invisible People. Lahore: Sang-e-Meel, 2017. Print.

Shamsie, Kamila. Home Fire. New York: Riverhead Books, 2017. Print.

Spivak, Gayatri Chakravorty. A Critique of Postcolonial Reason. Harvard: Harvard UP, 1999. Print.

Vinayaraj, Yahu T. "Spivak, Feminism, and Theology". Feminist Theology 22.2 (2014): 144-156.

Yousaf, Nahem. "Hanif Kureishi and 'the brown man's burden'”. Critical Survey (1996): 14-25. Print.

Wright, Eric Olin. "The comparative project on class structure and class consciousness: an overview”. Acta Sociologica 32.3 (1989): 3-22. Print. 